\title{
The balance between teaching and research in Dutch and English universities in the context of university governance reforms
}

\author{
Liudvika Leisyte $\cdot$ Jürgen Enders $\cdot$ Harry de Boer
}

Published online: 3 March 2009

(C) The Author(s) 2009. This article is published with open access at Springerlink.com

\begin{abstract}
The expectations and demands with respect to teaching and research have been changing for universities due to changes in their institutional environments. Born out of changing national research policies and modern governance arrangements, efficiency, effectiveness and output-oriented cultures have become increasingly important. In this article we ask the question of what the consequences of these changing institutional environments are for the teaching-research nexus as experienced by academics at universities. We explore the changing practices of teaching and research in eight research units in research-led universities in England and The Netherlands. The sources of our empirical investigation are documentary evidence as well as interview data from 48 academics in biotechnology and medieval history. Our findings suggest that teaching and research are increasingly falling apart as two distinct activities. Success or failure in research acquisition and performance assessments has serious implications for the work portfolios in terms of teaching and research load of the research units.
\end{abstract}

Keywords Teaching-research nexus $\cdot$ Higher education policy $\cdot$ Research practices $\cdot$ Academic work $\cdot$ Biotechnology $\cdot$ History

\section{Introduction}

In higher education and research systems a whole range of reforms have taken place across Europe in the past two decades. Governance systems - the steering and coordination of interdependent (usually collective) actors based on institutionalized rule systems (Benz 2004)—have been 'modernized'. The changing relationship between state, society and institutions, the increasing demands and expectations on higher education institutions and

L. Leisyte

The Minda de Gunzburg Center for European Studies, Harvard University, Cambridge, MA, USA

L. Leisyte $(\varangle) \cdot$ J. Enders $\cdot$ H. de Boer

Center for Higher Education Policy Studies, University of Twente, P.O. Box 217, 7500AE Enschede, The Netherlands

e-mail: 1.leisyte@utwente.nl 
the recognition of their growing importance in a knowledge society, have created a rethinking and repositioning of universities and their main functions. Amongst other things, current higher education and research policies increasingly question the functionality of a strong teaching-research nexus in Europe. Although in many debates on higher education and research a close link between these two key functions of universities is assumed, historically this connection is uncertain and conditional (Wittrock 1985, p. 15).

In this article we ask the question of what the consequences are of such 'modernised' governance structures for the teaching-research nexus as experienced at the shop floor level of universities. How do academics respond to their changing institutional environments as regards their teaching and research portfolio? Answering this question will contribute to the debates on the change and stability in the teaching-research nexus in higher education and research systems (Brew 2006; Clark 1991, 1996, Colbeck 1998; de Weert 2004; Deem and Lucas 2007; Jenkins et al. 2003; Durning and Jenkins 2005; McNay 1999; Smith 1999; Taylor 2007). In particular, it will help to understand what the higher education and research reforms at the macro level may mean for the basic functions of university research units. Our research focuses on two fields of research-medieval history and biotechnology-and explores the perceptions and experiences of academics in eight research units in England and The Netherlands. Our analysis is based on a secondary analysis of national and university documents and white papers as well as on interview data from 48 academics. The interviews in eight research units in biotechnology and medieval history have been conducted in 2003 .

The article starts with conceptual premises of understanding the teaching-research nexus and the environmental factors that challenge this nexus in England and The Netherlands. After this review of the conceptual and contextual underpinnings, the study's methodology is presented, followed by the empirical evidence from the eight research units. Finally, the concluding part reflects on the impact of 'modernised' governance on the teaching and research activities of the selected research units.

\section{Different views on the teaching-research nexus}

The teaching-research nexus is a long debated and yet highly controversial issue (e.g., Neumann 1992). "No issue is more basic in modern higher education than the relationship between research and teaching. And no issue occasions more superficial thought and retrogressive criticism both outside and inside the academy" (Clark 1997, p. 241). Many different views exist, ranging from a positive to a negative relationship as well as the nonexistence of the nexus (e.g., Hattie and Marsh 1996; Elton 1986; Coate et al. 2001). Review studies provide no conclusive answers and report many difficulties in determining and measuring the connections between 'the discovery of knowledge' and the 'transmission of knowledge' (e.g., Neumann 1994, 1996; Hattie and Marsh 1996; Zubrick et al. 2001).

Schimank and Winnes (2000) differentiates between three principle models or types of relationship between teaching and research. First, the pre-Humboldtian model is exemplified by the French system of higher education where research and teaching are separated in different institutions. This institutionalised division of universities and research institutes dates back to the 18th century. According to this model, research is carried out separately from teaching and was deemed to be mainly a researcher's own scientific inquiry (Schimank and Winnes 2000, p. 404). This model has been widely used in Eastern Europe and Russia. The second model concerns the modern idea of an interrelated unity of 
research and teaching. It stems from Wilhelm von Humboldt's nineteenth century university ideal and emphasizes the integration of teaching and research with a heavy assignment of research to universities and a blending of teaching and research in the professorial role (Clark 1983, p. 98). Professors and students were linked through research in "a common search for truth, in the form of new knowledge" (Ibid, p. 100). This combination of teaching and research was declared as an important tenet of scientific education (Henningsen 2006, p. 98). The third model is the post-Humboldtian pattern characterized by "a differentiation of roles and/or organizations and/or resources for teaching and research" although both roles are expected of academics at a university (Schimank and Winnes 2000, p. 398). This pattern goes further than the Humboldtian type in terms of differentiation between the two activities as it is to some extent found in the UK.

In a different way these models can also be found in Ramsden and Moses' (1992) distinction. They discern three views as regards the teaching-research nexus: the strong integrationist view, stressing the close connection at the individual level, the integrationist view, indicating a link at the departmental or institutional level, but not necessarily at the individual level and the independence view, claiming no causal relation between teaching and research. The proponents of the strong integrationist view stress the synergy possible by combining teaching and research. It represents Hattie and Marsh' (1996, p. 511) "conventional wisdom model", basically arguing that in higher education you cannot be a good teacher unless you are a good researcher and vice versa. Research indicates that academics have a common belief that teaching and research are positively correlated (e.g., Smeby 1998). Smeby (1998) adds that academics also believe that research is more important for teaching than the other way round. According to Geiger (1985, pp. 54-55), the significance of the nexus can be distinguished at three different levels. First, it is intellectually useful for researchers to teach so they get acquainted with material wider than just their own research; teaching also requires new impetus and knowledge from research. Additionally, teaching supplies professional opportunities for researchers since positions in universities have traditionally been created mainly for teaching purposes while these positions also provide opportunities to do research. Finally, a distinctive feature of universities is their research training function for doctoral students (and post-doctoral junior researchers), where teaching and research are intrinsically intertwined (Geiger 1985, p. 54).

At the same time, empirical studies question the benefits of the strong connection between teaching and research, if there exists a relationship at all (Brew and Boud 1995; Neumann 1994, p. 323; Centra 1983, p. 379; Hattie and Marsh 1996, p. 529).

The likelihood that research productivity actually benefits teaching is extremely small or that the two, for all practical purposes, are essentially unrelated (...) Productivity in research scholarship does not seem to detract from being an effective teacher (...) We must conclude that the common belief that research and teaching are inextricably entwined is an enduring myth. At best, research and teaching are very loosely coupled (Hattie and Marsh 1996, p. 529).

This conclusion supports Ramsden and Moses' independence view and might indicate that research and teaching are different activities or that researchers and teachers are different kinds of people, having few personality attributes in common.

Other studies revealed an inverse relationship between teaching and research (e.g., Pascarella and Terenzini 2005). Hattie and Marsh (1996, p. 508) provide three arguments for such a negative relationship. Their scarcity model suggests that teaching and research 
are in conflict with each other and compete for time, energy and commitment. Research competes with teaching obligations for time and content with teaching suffering as a result (Zubrick et al. 2001). For example, students find the availability of teachers important and this availability in research-led universities — driven by academic prestige primarily based on research performance-is frequently perceived as limited. Second, their 'differential personality model' proposes that the two activities require contrary personal orientations. Third, according to the 'divergent reward system model' "research and teaching are conflicting roles with different expectations and obligations that are motivated by differing reward systems" (Ibid., p. 510).

Thus, empirical evidence for the existence and benefits of the nexus are thin, although such conclusions might be due to particular research designs that do not cover the full complexity of the nexus (e.g., Zubrick et al. 2001). The nexus can be subtle and indirect. Smeby (1998, p. 18) argues that an indirect nexus not necessarily means a weak interaction. "On the contrary, there are indications that the interfaces are important and manifold" (Ibid.). Because the issue is complex and multilayered and the research outcomes are ambiguous, further research is welcome. Recently, as Jenkins (2004, p. 7) reports, "a range of new research areas have developed, including how issues of departmental and institutional structures, cultures and policies shape teaching-research relations, and how the character of disciplines, and their conceptions of knowledge and forms of research, impact on teaching-research relations". For example, academics tend to perceive the unity between teaching and research differently depending on their disciplinary background (Moses 1990; Becher and Trowler 2001; Healey 2005).

We aim to contribute to these new areas of research. Our point of departure is that the nexus is not a static concept; it is contingent on changing contexts. While the Humboldtian ideal of the unity between teaching and research is still appealing to many and alive in several countries' policy discourses (Schimank and Winnes 2000), there are good reasons to believe that the changes in higher education and research systems in the last half century have increasingly put pressure on the connection between these two university functions. Among other factors, shifts in governance arrangements regarding higher education and research systems have contributed to a large extent towards rethinking the balance between the two major university functions and their interface (Leisyte 2007).

\section{Methodology}

The sources of the empirical investigation of our study are the documentary evidence as well as interview data from 48 academics, collected in eight research units in biotechnology and medieval history in 2003 in England and The Netherlands. Our study is an exploratory inquiry which looks at similarities and differences between research units in public universities at a given moment of time across two countries (Leisyte 2007). It is based on the case study design in which the university's research unit is the unit of analysis. These units, organisationally embedded within faculties, departments or research institutes of universities, have their own academic existence and are regarded as the smallest organisational, 'collective' part of a university.

The medieval history research units are loosely organized within the English departments and within the Dutch research institutes. Usually a medieval history research unit devotes its research time to the 'same' overarching thematic area, collaborates in teaching in the same Masters programme, organises conferences and collaborates in externally funded research projects. Medievalists form a recognizable unit with its distinct identity 
although the dominant working style is individualistic. Within the research units, both senior and junior staff members are engaged in teaching.

In biotechnology research units, the team spirit is very high and team work is clearly noticeable in every day work in research laboratories. One English research unit is embedded in a department that comprise in total 38 FTE. The other English research unit is part of a research institute that has around 100 FTE. The two Dutch research units are organisationally embedded in research institutes, each having around 100 FTE. The academics within the research units tightly collaborate with each other, working on the same bacteria or protein. They strive to investigate the research problems collaboratively while engaging in externally funded projects. Teaching is usually carried out by senior academic staff, unless it concerns lab tutorials where post docs contribute to teaching.

The fields of research are selected according to the dichotomy of monodisciplinary versus multidisciplinary research as well as humanities versus sciences to account for the disciplinary differences (Becher and Trowler 2001). The underlying logic is to explore the teaching-research nexus for both Mode 1 and 2 types of knowledge production (Gibbons et al. 1994) and to account for the 'hard' versus 'soft' fields of research (Biglan 1973). Therefore, the fields of medieval history and biotechnology are selected.

Another aspect in the selection of research units in England and The Netherlands is the estimated quality of the research unit itself, distinguishing 'high achievers' and 'middle achievers'. The assumption is that (past) performance of the research unit may have an impact on its response towards changing circumstances. One might argue, for instance, that middle achievers must respond to institutional changes to survive or that they see shifts in governance as a means for closing the gap with the high achievers.

We selected the research units within universities on the basis of research performance/ quality. For this purpose, we looked at the available public rankings and national research evaluation results for those universities that have the research fields of medieval history and/or biotechnology. This implied a focus on 'old' universities in England and comprehensive research-based universities in The Netherlands, because these institutions have in comparison with other higher education institutions in the two countries a strong research focus. In this paper, we present the following cases named alphabetically (Table 1).

The interview data were analyzed on the basis of similarity into coded categories, which was achieved with the help of coding for subject matter and meaning (Luborsky 1994). We started with open coding and further turned to selective coding. Dense systematic analyses were made. After having decided the core categories, they were connected to each other and the major core. A peer review and structured analysis were used to enhance the validity of the data categorization and of the interpretations (Straus and Corbin 1990). For the analysis, citations that best represent a category or opinion as expressed by the majority of the interviews were used to highlight our findings.

Table 1 The selected cases of the study

\begin{tabular}{lll}
\hline Field of research & England & The Netherlands \\
\hline Medieval history & Case A (middle achievers; 10 FTE) & Case C (middle achievers; 22 FTE) \\
& Case B (high achievers; 6 FTE) & Case D (high achievers; 12 FTE) \\
Biotechnology & Case E (high achievers; 11 FTE) & Case G (high achievers; 14 FTE) \\
& Case F (middle achievers; 14 FTE) & Case H (middle achievers; 24 FTE) \\
\hline
\end{tabular}


Before we turn to the research units' responses, in the following section we describe the first part of our analysis, i.e., the shifts in the higher education and research systems, the context within which the teaching-research nexus is being reconsidered.

\section{The teaching-research nexus in a changing context}

There are a number of interrelated factors in the academics' environment that potentially affect the teaching-research nexus. The overarching factor is the growth of the higher education and research sectors (mass higher education and continuously expanding scales and scopes of the knowledge base). For universities demand overload is the consequence of these growths: "Universities are caught in a cross-fire of expectations. And all the channels of demand exhibit a high rate of change" (Clark 1998, p. 131). Among other things, due to unprecedented expansions scarcity of public funding has become one of the pressing issues. And for various reasons competition for scarce resources-students, research grants or excellent staff-has intensified. These harsh realities with concerns about the affordability of public sectors on the one hand and the acknowledgement of the prominent place of universities in the emerging knowledge society on the other hand, have led to a range of policy reforms in almost every country. In modernizing their higher education and research systems governments as well as universities introduced a spectrum of new policies and strategic initiatives.

In general these policies and initiatives had an instrumental view, stressing economic values such as effectiveness, efficiency and economy instead of traditional academic values. Governments and universities are pressing for more and better teaching as well as for more and better research outputs. 'Doing more with less' and under the assumption that teaching usually earns less credits than research (e.g., Lucas 2006), conflicts between teaching and research are likely to happen. As Ben-David reported for the US already in 1972, "the basis for the unity of teaching and research has been weakened by the rapid rise of university research that has little or no connection with teaching, and by the rapidly growing imbalance between the rewards for research and those for teaching" (Ben-David 1972, p. 112).

Moreover, because of limited public funding available academics are increasingly expected to spend time on acquiring external research funding if they want to continue their research activities. In their search for external funding academics face conditions that are new to a large extent. Increasingly research grants must be obtained on a competitive basis. And external sponsors introduced new rules such as the formation of international consortia as a prerequisite for grant application. Such research-related activities take away time both from teaching and research itself and call for a reconsideration of the teachingresearch nexus.

In this dynamic context, both governments and universities in rethinking the university's position launched many reform policies that are directly or indirectly affecting the nexus. At many universities for example, profiling, institutional reputation building and tendencies of both academic and vocational drift have fuelled debates on balancing teaching, research and community services. In the pursuit for excellence (in both teaching and research) and for more intra-organisational efficiency universities introduced rationalisation policies to further streamline their organisations. Quality assessment schemes and other monitoring devices are examples for this and again such new rule schemes are likely to take away time and energy available for the primary processes. 
These general patterns are also noticeable in England and The Netherlands. While the higher education and research systems of these two countries differ in many respects and reforms and other system changes have been introduced at different times and scales, developments such as mass higher education, the rapid expansion of the knowledge base, restricted public expenditures, increased competition and marketisation, internationalisation, the introduction of new funding and quality assessment schemes, increased focus on excellence and strengthened university leadership are clearly visible.

For a more detailed description of the changes in these countries see Leisyte (2007). The expectation is that these developments have an impact on the teaching-research nexus as experienced at the shop floor level. In the next section we will describe how English and Dutch medievalists and biotechnologists respond to their changing institutional environments when it comes to the nexus.

\section{Evidence from the case studies}

\section{Medieval history units}

The two medieval history research units in England are involved in teaching and research and believe they should do both. They perceive a growing tension between these principal activities; there is "a subtle but significant shift of emphasis away from teaching and towards research and releasing the research time" as noted by one junior researcher. Teaching has traditionally been very important in the field of medieval history as one professor remembers well:

When I was young, there was much less research been carried out, it was not considered a necessary part of being a university teacher, you were there to teach. And if I researched that was a luxury and extra private hobby that was good for department, but not essential.

Currently most researchers in the English medieval history units observe changes in the teaching-research nexus. The importance of research has increased, encouraged by university management partly due to the RAE demands and the need to attract external funds. Research has become more visible and monitored in both units. At the same time, all respondents report increased teaching loads due to increased numbers of students. In case A (middle achievers) with declining staff numbers and increased workloads a sense of despondency exists. A professor, who was losing holiday time due to the marking of exams which he planned to spend on research, thinks this situation is unacceptable:

The system is not working together. It is changing so fast, developing in contradictory patterns. And there is no overall planning for it. We are trying to monitor it, but we have no power to change things. Monitoring shows up absurdities; all we can do is drink coffee and complain.

The situation in case B is better in this respect, since their university management seems more accommodating. For example, according to a professor, junior researchers have reduced teaching loads and all staff has periodical research leave more frequently than a decade ago. However, views differ: a junior complains about the lack of research time. He says junior researchers spend around $40 \%$ or less of their time on research, while the rest goes to teaching and administration. This means that roughly $60 \%$ of their working time 
goes to preparation for and teaching of classes, correcting exams, student supervision and related paperwork and meetings.

Both research units find this situation in general dissatisfactory. They would like to have more time for research, important as this is for building credibility toward promotion or obtaining external funding. The imbalance between teaching loads and research significance puts the system under pressure and contributes to work intensification. This is reinforced by contradictory signals from institutional management, sanctioning bad research performance with higher teaching loads. Underperformance related to the RAE is not without consequences. For example, a junior researcher from case A is told by the department management that he needs to produce a book for the next RAE on time if he wants to be promoted to senior lecturer. The 'threat' not only concerns promotion, but is also about being marginalized and going for 'only' a teaching position. As a case B professor mentions:

If a member of staff doesn't publish in such a way that they meet the requirements of the RAE, the university could and does on occasion put quite serious pressure on them in terms of their position and their appointment, they are after all not doing the job. But I cannot say that the university is being particularly pro-active or stern in such matters.

As a consequence teaching is increasingly seen as a punishment for not producing good enough research outputs. For example, in case A the punishment is evident to be "pushed into a more teaching-only role". Teaching is not rewarded as well as research: "you don't get famous being the world's first best teacher" another junior from case A reports.

Researchers in both English medieval history units react to the conflicting demands by long working hours, trying to do both teaching and research even if it means working during their spare time or holidays. Encouraged by their management, they apply for external funding to 'buy out' teaching and make time for research. Finally, they pass teaching on to non-research active academics or contract staff. Research unit A thinks this tendency to 'buy out' teaching is unfortunate because academics may lose the feeling of the importance of teaching: a neglect of teaching is "forgetting why we are here". Also the management's tendency to reward external research funds at the expense of teaching is seen as regrettable. The quality of teaching can be in jeopardy.

Researchers from both medieval research units fear that a stronger division between teaching and research is likely to continue in the future, as a researcher in A articulates well:

What I suspect is that the British love affair with tailoring teaching and research very closely will come under strain because we are teaching less. And there are few opportunities to teach your research to people, even at postgraduate level. So we might get a system which I think is in embryo now; which is where some institutions, which are research active, become more and more research institutes with the postgraduate students. And then there will be other universities which are essentially just teaching institutions. And if you can do a bit of research, good luck to you, but you are not going to be paid to do any. In a sense the British system at the moment is a sort of unholy alliance between those two tendencies and I think they develop like that.

Respondents from the two Dutch medieval research units argue that the teachingresearch nexus is influenced by increasing student numbers. They spot a tendency towards a separation of teaching from research. They feel compelled to increase their teaching 
loads since funding is (partially) based on student numbers. Moreover, if a researcher wants a permanent staff position, s/he has to teach. But for getting teaching experience, a junior researcher has to use the post-doc time in principle meant for doing research. Both research units underscore that due to higher student numbers research time has been compromised. As a result, a D junior researcher emphasizes the lack of space for research:

So I am teaching, teaching, teaching and sometimes when I have 5 minutes of breathing space then I breath and if I have 5 minutes more than I work at a big edition project... we are in the middle of this chaos and it's lots of fun but research is not happening much I must confess.

Time pressures arise because of growing student numbers and capacity problems:

The number of hours we have to teach has doubled, whereas the number of students who want to study has tripled or quadrupled even. And the number of people who are expected to do all this has decreased. You can sort out the puzzle by yourself. I take the junior teaching staff, AiOs, for a drink every week, so they can unload their stories. First years (...) are getting stressed out with teaching. Of course we try to keep things as relaxed as possible and it is only a quarter of the year (...), but this is crazy. We really need more people; we don't have enough hands for anything, but still we have to do it.

Since there are such high teaching demands, even on juniors such as $\mathrm{PhD}$ students, almost all are highly dissatisfied with the lack of time to carry out research. This leads to growing workloads and overtime during the weekends and their holidays, as expressed in case D: "But I notice that if I want to keep up with the usual matters, then I have to work much more hours than the official office hours and as a consequence of 'rush orders' holidays evaporate."

Although feeling unhappy about it, they are complying with the increasing teaching demands. They also fear that "new teaching courses get increasingly loosened from research", which is another shift that is not welcomed.

In terms of teaching and research loads, the situation of the juniors in the two research units differs. There are juniors in both units who are obliged to teach a substantial amount of hours (in research unit D because of a professor's sabbatical, for example), whereas other junior researchers are mainly involved in research projects. Those concentrating mostly on research are mainly funded by the national research council. According to the council requirements, only a small fraction of their time can go to teaching, meaning teaching is 'incidental.'

More teaching also implies more administrative tasks, as experienced in both cases. It can easily 'eat' research time as expressed by the leader of D: "It means that you say 'okay' for reasons of loyalty. I will give an additional tutorial to take care of it, but this goes at the expense of the time for doing research".

A senior from case $\mathrm{C}$ observes an increasing number of meetings and committees due to the introduction of the Bachelor-Master structure and together with the increased student numbers this indeed compromises research time. He does not appreciate the resulting complexity in the institutional governance structure:

I think when I look at 30 years ago there was more room and time for research. The organisation, committees, we now have this bachelor-master (...). The situation where we are working and living in is completely ridiculous. This is also takes time 
away from research. And it is not only time, but energy. And my predecessors did not have that problem at all.

Since there is according to the respondents less time available for research, the traditional outputs in this field such as sizeable books are becoming increasingly difficult to produce. As expressed by the $\mathrm{D}$ research unit leader, teaching and administration disturb the concentration on producing research, which results in short papers that require less time.

Institutional management has taken some initiatives in relation to the increased teaching loads. In case D, institutional management is offering a 'teaching free' period for post docs to do primarily research (although management thinks it is good for post-docs to get teaching experience). In case $\mathrm{C}$, institutional management encourages short-term teachingonly contracts through their funding arrangement of research institutes. A junior researcher is concerned about such staff appointments since if they become teachers 'only' who do not belong to the research institute and consequently do not get funding for research:

It is true that it is much stricter at the individual level. For example, there are sufficient people here that have had a temporary contract for years and partly a teaching appointment. They publish small numbers and hence they are not part of the research institute. As a consequence of this, they do not get any money anymore to do research.

To conclude, as regards the teaching-research nexus we clearly see that the researchers of both the English and the Dutch medieval history units note a change in division between time for doing research on the one hand and doing other things (particularly teaching) on the other. This change is partly due to the increase of student numbers. When staff numbers do not go up, this simply means that teaching is requiring more time. In The Netherlands the introduction of the Bachelor-Master structure has further increased teaching-related time, partly because of accompanying bureaucratic burdens. Academics report that teaching is increasingly taken away time from doing research. At the same time, the importance of research is growing. In England particularly because of the RAE the importance of research has grown. Researchers choose to work additional hours during the weekends and even give up parts of their holidays to carry out research, and to be sufficiently productive. In England, researchers try to take research leave as often as they can, sponsored by the university or externally. There is a feel that teaching is regarded as 'less important', that universities are hiring temporary staff for teaching and that 'teaching only' positions are a 'punishment'.

\section{The biotechnology research units}

The two biotechnology research units in England have different traditions of balancing teaching and research practices. Traditionally, research unit E has been involved in both teaching and research, whilst unit F was mainly dedicated to research as it had stable funding for 10 years just to carry out research. However, due to the latest RAE results, research unit $\mathrm{E}$ received a substantial increase in funding and consequently started to teach less. Research unit F experienced a halt in the unit's core funding, so they decided to go for more external research funding as well as to start teaching. Both research units have an unconditional belief in the importance of research for academic reputation, future funding and professional careers. 
Respondents from both research units think that teaching and research become more separated due to the RAE and the related availability of research funding. High RAE scores imply better chances to secure additional funding from the research councils. As a result, there is less need to earn money through teaching, as the unit leader of research unit $\mathrm{E}$ indicates:

If you are in a highly rated department then it necessarily means that you've got staff. For first of all as a result of that you would be bringing in more income per staff in your block grant from the higher education funding council. But you'll also have a larger number of $\mathrm{PhD}$ students because that's the way it works. You'll also have more grants and more overheads. And therefore in order to pay all your bills you'll be less reliant on high undergraduate numbers. So your student to staff ratio will be more favourable and you'll be able to recruit smaller student numbers. So therefore you can afford to have students with higher A-level achievements and teach them. Because then you can have a coherent group. You can teach them to a similar standard and you can push them.

The leader of research unit $F$ notes that such trends will lead to further stratification of research and teaching, especially in terms of teaching and research-only appointments. $\mathrm{He}$ reports that this can become a sector wide development:

There will certainly be a creation of what I would call a predominantly or entirely teaching appointment. And there is going to be a shift to that cohort, the teachers. It may be that they aren't there permanently, that you come in and out of that cohort. I think though that there will be the majority who have a reasonable teaching load and are recognized as doing acceptable research and there will be another minority at the seriously high end, where either relatively new professors or people really pushing very hard in research front, and they will be seriously protected. So there is kind of stratification that is going to happen.

Besides the focus on research performance, respondents of case $E$ also say that the increased numbers of research student are another reason for the change in the teachingresearch nexus. The growth of these student numbers increase the research potential.

In research unit $\mathrm{F}$ core funding has stopped and their staff had to go to the departments to take on teaching responsibilities. The core staff of this research unit is attached to different disciplinary departments and their responsibilities in teaching are related to the changes in student numbers in those departments:

If you say that the people who are the core staff are the real drivers of $(\ldots)$, who give its name outside, who contribute to scientific ideas, than we have to say that unlike me, they are not immune. They in their home departments have teaching loads, some of them are quite serious, so how much time they devote to their research, and therefore how much kind of (...) relationship and focus there is, is limited. And so there is an impact on them. Teaching is quite a demanding thing now, not the least because we all try to increase teaching numbers, and teaching quality is affected to some degree.

In both cases junior respondents have limited teaching responsibilities; their primary goal is project-based research work. For them it is natural to start as a post-doc and concentrate only on research and start teaching when one's position has become permanent. Both units employ juniors only on short-term post-doc contracts with limited teaching responsibilities. The rationale behind such an arrangement comes from the senior 
researchers, the departmental management, and the external grant giving bodies, aiming to devote time to juniors to build their research experience and learn how to obtain funding. In other words, to build their researcher's credibility and work on externally funded research projects.

In both research units researchers are not too keen on teaching, particularly in case E. They are reluctant to teach (extensively) and see it as a penalty coming from institutional management; if a researcher does not manage to get research funding and cannot easily switch to a different research area, then s/he should change to administration or a teachingonly position. Obviously this is not appreciated by researchers as reported by the senior researcher of the well performing unit: "I guess if one was extremely well funded to empower research would be able to fight against the amount of teaching if one wished to. But I am not in that position, so my teaching load increases".

In terms of the mix of teaching and research activities, both English biotechnology units comply with the funding demands in their environment. With the increase in research funding $\mathrm{E}$ is teaching less, whereas after the cessation of stable funding $\mathrm{F}$ researchers got more involved in teaching. Both research units employ the strategies to diversify junior staff into research-only and mixed positions to secure the needed critical mass for both activities and select the research talent.

The Dutch biotechnology research units are mostly involved in research and teach (far) less than half of their time. Research is their 'core business'. Both research and teaching are main tasks of the researchers and their units. They are both evaluated and related to funding. There is a common point of view among the researchers that the teaching-research nexus is influenced by changing student numbers, reduced number of permanent staff, and changing faculty policies towards the separation of teaching from research.

There is quite a difference between junior and senior researchers. Juniors are supposed to be more involved in research than in teaching. A junior researcher, who agrees that their teaching workload is smaller than those of seniors, adds that their teaching loads are higher than they used to be. Teaching loads used to be about $10 \%$, but things have changed due to a decrease in staff numbers and a simultaneous increase of student numbers. Increased teaching workloads are experienced in both research units:

Staff members have a $60 / 40$ or $70 / 30$ appointment, which means either 40 or 30 percent of the time is spent on lecturing. This pressure is becoming bigger because the student numbers are increasing and the number of staff is declining.

High performing biotechnology unit $\mathrm{G}$ foresees a (growing) problem in the future regarding the declining capacity for teaching, particularly since the university intends to introduce a system of bursary $\mathrm{PhD}$ students. ${ }^{1}$ These bursaries will not be obliged to teach, in contrast to AiOs. This would further reduce the teaching capacity of the research unit.

The changing balance between teaching and research disturbs the researchers without exception. They argue that they can not afford to lose (too much) research time because of higher teaching loads. They see research as crucially important for the unit's reputation: "During a study you don't want to spend $70 \%$ of your time with teaching, because you don't get around to doing research", a researcher from research unit $\mathrm{H}$ admits. Without downplaying the importance of good teaching, they have to produce research outputs,

\footnotetext{
${ }^{1}$ In The Netherlands doctoral candidates can be staff members with an employment contract; they are then called AiOs. Doctoral candidates can also be funded via other sources such as fellowships and do not hold a status as staff. Then they are called bursary students.
} 
especially publications; this is the crucial capital for researchers. Peer review-based evaluations look at both teaching and research, but external funding bodies mainly look at research performances. Eventually research performance determines the standing of an academic group:

The visitation committee evaluates both. But, for example, when you have to prepare your yearly reports for the research school and NWO [national research council], it is only research. So how well you teach, 'nobody' cares about that; the only thing that counts is your publications. You cannot publish if you do no research and with teaching it won't help too much. So that can become a problem if you are not publishing enough. And you have less chance in your grant application...you have to be a bit careful with that.

Therefore, tensions are clearly noticeable. As a result of an increased pressure to teach more and to balance all the activities, time constraints have been a dominant theme in both research units. The lack of time for doing research is frequently put forward. A junior from research unit $\mathrm{H}$ confirms the competition between teaching and research time: "Of course the more time I spend on teaching the less I have for research". Less time for research provides a bleak picture for the competitive future of a researcher. Because academic careers are 'research-driven', serious teaching loads may worsen career opportunities, as a junior from $\mathrm{H}$ argues: "I think in the future I will have to spend more time teaching and that makes it worse, it makes it harder to survive in this research world. On the other hand, I think I become more experienced."

This quote signals that teaching may have its advantages as well. Gaining experience is one of them. Another potential advantage put forward by a junior researcher concerns seeing teaching as an investment for the research unit's future $\mathrm{PhD}$ generation; it is a pool of resources. And as we see below, master students can participate in research projects. In this respect, research projects can benefit from teaching engagement.

The common strategy of both research units to cope with the 'multi-tasking' of individual staff members, and especially with the increased teaching load, is to work additional hours. Working during the evenings and weekends is a common characteristic in both research units. It seems to be part of the life of the modern academic:

I do a lot in the evening and at home with the computer. So the reading, writing, correcting manuscripts, that's usually at home. And here [at the university] it's more like talking to people and managing, solving problems, all kinds of different things. You have a lot of distractions when you are here. When I'm home I can do some reading and writing.

With the tensions between teaching and research clearly observable, the majority of the researchers in research units $\mathrm{G}$ and $\mathrm{H}$ believe that they must go together: research is needed to 'feed' the teaching. Moreover, masters students, in spending time the in the lab, can be helpful in running experiments and contribute to the overall research processes and outputs. As a junior researcher from research unit $G$ pragmatically explains the utility of students in their research:

We have the supervision of master students who will work for half a year on a research project and you have to supervise them because they have never really worked in the lab. This takes a lot of time, but can also be very rewarding because they can do a sub-project and some of your work. If they are reasonably good you can also use it for the rest of your research. If they are really bad, it just takes a lot of 
time. The pay-off is clear. Most people do not really object, because they take some of your work out of your hands.

A leader of research unit $\mathrm{G}$ takes this point further. In his view, teaching and research cannot be stopped at the expense of each other. The major problem of separating teaching too much from research is that teaching will suffer from a lack of expertise if a particular research is not carried out at that university. Two juniors explicitly expressed their concerns about the possible separation of teaching from research in the future when the university would become a 'teaching-only' institution and research is carried out in separate research institutes.

To conclude, the researchers of the English and Dutch biotechnology research units report changes as regards the teaching-research nexus. This nexus is not questioned by itself; in fact, most of the researchers see this as something good, even if research is indisputably seen as the cornerstone of their raison d'être. Nevertheless, for three of the four research units teaching loads have gone up. This seems particularly true for senior researchers; juniors are supposed to be more engaged in doing research. Increased teaching loads are partly due to an increase of student numbers, partly due to staff reduction and partly due to university policies. Heavy teaching loads, however, are not wholeheartedly embraced since eventually research performance is what really counts. In England, the RAE underpins the importance of research performances having direct effects for the teaching-research balance. In general, for reasons of job loyalty academics report they do what needs to be done and try to handle the situation as good as possible. Depending on personal ambition, biotechnology researchers report long hours to carry out their research in trying to be sufficiently productive and avoiding getting marginalised.

\section{Conclusion}

We are interested how shifts in governance in higher education and research systems influence the teaching-research nexus, one of the abiding issues in higher education. With respect to this nexus, our research intends to contribute to the news lines in research in this area (Jenkins 2004, p. 4). In the two higher education and research systems at issue, England and The Netherlands, various changes have been observed that may have an impact on the nexus. Mass higher education, the rapid expansion of the knowledge base, restricted public expenditures, marketisation, internationalisation, new funding and quality assurance schemes, and strengthened institutional leadership have created new realities for academics.

The responses of eight research units in medieval history and biotechnology have revealed that the changing institutional environments have influenced the teachingresearch nexus. In coping with budgetary pressures, research-based academic prestige and growing student numbers, English and Dutch research units have indeed reconsidered their teaching-research portfolio. On the one hand we witness support for this nexus. Many interviewees revealed clear indications in favour of the "conventional wisdom model" (Hattie and Marsh 1996, p. 511): teaching and research should be tightly coupled. It is also clear that in this integrated relationship most of the time research is seen as more important for teaching than the other way around (see also Smeby 1998), although occasionally academics said that research may benefit from teaching. On the other hand without exception the interviewees mentioned increased competition between teaching and research time, leading to intense conflicts in the work portfolio at the shop floor level. An 
increased administrative burden, particularly for senior academics, further enhances this time and energy competition. This is due to changes in the institutional environment, including intra-university policies using rewards and penalties via financial incentives and staffing policies. As Hattie and Marsh' (1996) scarcity model suggests, we found that research does compete with teaching obligations and vice versa. It is rather clear that researchers are suffering from the increased levels of competition, since driven by job loyalty they report long working hours and short holidays. In trying to survive harsh economic conditions and to provide both excellent research and teaching, demand overload lies in wait. Here the differences between the English and the Dutch and between the medieval historians and biotechnologists are relatively small: in order 'to keep the show going' work intensification is reported everywhere.

Moreover, nearly all academics observe-to their disliking-a change in the nexus towards separation of the two activities. Particularly institutional policies creating 'teaching only' positions are abhorrent to most academics. This shift towards loosening the nexus seems to be stronger in England than in The Netherlands. In England research performance, mapped by the RAE, has direct consequences for the unit's funding levels. Consequently, institutional management as well as the research units themselves make an all-out effort to look good on the research front, besides having intrinsic motivations to be excellent researchers. This outcome supports Ben-David's (1972) observation that the rise of research weakens the unity of teaching and research.

The well performing research units in England in both fields can afford to concentrate more on research, since they have high credibility within the university. Moreover, they receive internal benefits that sustain and reinforce their research base such as university funded research leaves or returned overheads. The low performers in England face seriously increasing teaching loads and have to work hard to enhance their research potential and to improve research performance. Low performers in research are instructed to focus on teaching. In the Dutch medieval history cases there is a serious increase in teaching workloads as a result of increased student numbers combined with limited staff capacity and the introduction of Bachelor-Master structure. For Dutch medievalists teaching is a source of substantial income, particularly because their contract research income is limited. Their strategies focus on hiring temporary staff to teach and on involving junior researchers in teaching. There is no clear difference between the high and medium performers. Both Dutch medieval history research units involve juniors in teaching, which indicates that there is not much difference in their approaches in this respect. For the Dutch biotechnology research units research remains the major activity, although they increasingly face diverse tasks of research, teaching and administration. Also here according to our findings not much difference between the high and medium performers exists.

The outcomes of our study link up perfectly with the conclusions drawn by Coate et al. (2001, p. 158). They say "while the ideal relationship might be perceived by many academics to be a positive one, there are a number of factors that shape the ways in which teaching and research can have a negative influence on each other, or even be driven apart. These factors include pressures to compartmentalize teaching and research through accountability and funding mechanisms, management strategies of academic staff that treat teaching and research separately, and the competition for scarce resources".

However, as described earlier in this article research does not provide conclusive answers with respect to the complex relationship between teaching and research. If the respondents' views are correct, indicating a weakening of the interrelated unity of teaching and research, the post-Humboldtian pattern, characterised by differentiating roles and resources for teaching and research, is on its way. For those believing in the virtues of the 
classical Humboldtian ideal of a strong integration between the two, this is a nightmare; those claiming an inverse relationship between teaching and research will show a nod of approval; and those convinced there is no relationship whatsoever will shrug their shoulders. Our research suggests that many of our interviewees must have the feeling of a bad dream as their answers indicate a continuous belief in the teaching-research nexus.

Acknowledgments We acknowledge the support for this study from the German Research Foundation (DFG) for the project "Comparative Study on Management and Self-governance Models" in the period 2003-2006. We also acknowledge the further support of the DFG during 2006-2009 for a second stage of the overall project. This will allow us to revisit the countries and research units under investigation in this paper. The authors of this article would like to thank the other researchers in the project team Prof. Barbara Kehm, Dr. Ute Lanzendorf and Prof. Uwe Schimank for their contribution.

Open Access This article is distributed under the terms of the Creative Commons Attribution Noncommercial License which permits any noncommercial use, distribution, and reproduction in any medium, provided the original author(s) and source are credited.

\section{References}

Becher, T., \& Trowler, P. (2001). Academic tribes and territories (2nd ed.). Buckingham and Philadephia: SRHE/OUP.

Ben-David, J. (1972). American higher education. Directions old and new. New York: McGraw Hill Book company.

Benz, A. (2004). Governance-Regieren in komplexen Regelsystemen: Eine Einführung. Wiesbaden: Verlag für Sozialwissenschaften.

Biglan, A. (1973). The characteristics of subject matter in different academic areas. The Journal of Applied Psychology, 57(3), 195-213. doi:10.1037/h0034701.

Brew, A. (2006). Research and teaching: Beyond the divide. London: Palgrave Macmillan.

Brew, A., \& Boud, D. (1995). Teaching and research: Establishing the vital link with learning. Higher Education, 29, 261-273. doi:10.1007/BF01384493.

Centra, J. (1983). Research productivity and teaching effectiveness. Research in Higher Education, 18(2), 379-389. doi:10.1007/BF00974804.

Clark, B. R. (1983). The higher education system. Berkeley: University of California Press.

Clark, B. R. (1991). The fragmentation of research, teaching, and study. In M. Trow \& T. Nybom (Eds.), University and society. Essays on the social role of research and higher education (pp. 101-111). London: Jessica Kingsley Publishers.

Clark, B. R. (1996). Teaching, research, and quality in the twenty-first century. In S. Muller (Ed.), Universities in the twenty-first century (pp. 98-112). Providence: Berghahn Books.

Clark, B. R. (1997). The modern integration of research activities with teaching and learning. The Journal of Higher Education, 68(3), 241-255. doi:10.2307/2960040.

Clark, B. R. (1998). Creating entrepreneurial universities: Organizational pathways of transformation. Oxford: Published for the IAU Press by Pergamon Press.

Coate, K., Barnett, R., \& Williams, G. (2001). Relationships between teaching and research in higher education in England. Higher Education Quarterly, 55(2), 158-174. doi:10.1111/1468-2273.00180.

Colbeck, C. L. (1998). Merging in a seamless blend. The Journal of Higher Education, 69(6), 647-671. doi: $10.2307 / 2649212$.

de Weert, E. (2004). The organisational determination of the teaching and research nexus. Winchester, UK. http://portal-live.solent.ac.uk/university/rtconference/2004/resources/de_weert_paper.pdf. Accessed 14 Oct 2008.

Deem, R., \& Lucas, L. (2007). Research and teaching cultures in two contrasting UK policy locations: academic life in education departments in five English and Scottish universities. Higher Education, 54, 115-133. doi:10.1007/s10734-006-9010-z.

Durning, B., \& Jenkins, A. (2005). Teaching/research relations in departments: The perspectives of built environment academics. Studies in Higher Education, 30(4), 407-426. doi:10.1080/03075070500160046.

Elton, L. (1986). Research and teaching: Symbiosis or conflict? Higher Education, 15(3-4), 299-304. doi: 10.1007/BF00129218. 
Geiger, R. (1985). The home of scientists: A perspective on university research. In B. Wittrock \& A. Elzinga (Eds.), The university research system (pp. 53-77). Stockholm: Almqvist \& Wiksell International.

Gibbons, M., Limoges, C., Nowotny, H., Schwartzman, S., Scott, P., \& Trow, M. (1994). The new production of knowledge. London: Sage.

Hattie, J., \& Marsh, H. W. (1996). The relationship between research and teaching: A meta-analysis. Review of Educational Research, 66(4), 507-542.

Healey, M. (2005). Linking research and teaching exploring disciplinary spaces and the role of inquirybased learning. In R. Barnett (Ed.), Reshaping the university: New relationships between research, scholarship and teaching (pp. 30-42). Maidenhead: McGraw-Hill/Open University Press.

Henningsen, B. (2006). A joyful good-bye to Wilhelm von Humboldt: The German university and the Humboldtian ideals of "Einsamkeit and Freiheit". In K. Blückert, G. Neave, \& T. Nybom (Eds.), The European research university. A historical parenthesis. New York, Houndmills: Palgrave Macmillan.

Jenkins, A. (2004). A GUIDE to the research evidence on teaching research relations. York: Higher education academy. http://www.heacademy.ac.uk/resources.asp?process=full_record\$ion=generic\&id=383. Accessed 14 October, 2008.

Jenkins, A., Breen, R., Lindsay, R., \& Brew, A. (2003). Re-shaping higher education: Linking teaching and research. London: SEDA/Routledge/Falmer.

Leisyte, L. (2007). University governance and academic research. Case studies of research units in Dutch and English universities. Enschede: CHEPS, University of Twente.

Luborsky, M. R. (1994). The identification and analysis of themes and patterns. In J. F. Gubium \& A. Smakar (Eds.), Qualitative methods in aging research (pp. 189-210). Thousand Oaks, CA: Sage.

Lucas, L. (2006). The research game in academic life. Buckingham and Philadephia: SRHE/Open University Press.

McNay, I. (1999). The paradoxes of research assessment and funding. In M. Henkel \& B. Little (Eds.), Changing relationships between higher education and the state (pp. 191-203). London, Philadephia: Jessica Kingsley Publishers.

Moses, I. (1990). Teaching, research and scholarship in different disciplines. Higher Education, 19(3), 351-375. doi:10.1007/BF00133898.

Neumann, R. (1992). Perceptions of the teaching-research nexus: A framework for analysis. Higher Education, 23, 159-171. doi:10.1007/BF00143643.

Neumann, R. (1994). The teaching-research nexus: Applying a framework to university students' learning experiences. European Journal of Education, 29(3), 323-339. doi:10.2307/1503744.

Neumann, R. (1996). Researching the teaching-research nexus: A critical review. Australian Journal of Education, 40(19), 5-18.

Pascarella, E. T., \& Terenzini, P. T. (2005). How colleges affect students (Vol 2). A third decade of research. San Francisco: Jossey-Bass.

Ramsden, P., \& Moses, I. (1992). Association between research and teaching in Australian higher education. Higher Education, 23, 273-295. doi:10.1007/BF00145017.

Schimank, U., \& Winnes, M. (2000). Beyond Humboldt? The relationship between teaching and research in European university systems. Science \& Public Policy, 27(6), 397-408. doi:10.3152/1471543007 81781733.

Smeby, J. C. (1998). Knowledge production and knowledge transmission: The interaction between research and teaching at universities. Teaching in Higher Education, 3(1), 7-20. doi:10.1080/135621598 0030101 .

Smith, D. (1999). The changing idea of a university. In D. Smith \& A. K. Langslow (Eds.), The idea of a university (pp. 148-175). London: Jessica Kinglsey Publishers.

Straus, A. L., \& Corbin, J. (1990). Basics of qualitative research. Newbury Park, CA: Sage.

Taylor, J. (2007). The teaching-research nexus: A model for institutional management. Higher Education, 54(6), 867-884. doi:10.1007/s10734-006-9029-1.

Wittrock, B. (1985). Dinosaurs or Dolphins? Rise and resurgence of the research-oriented. In B. Wittrock \& A. Elzinga (Eds.), The university research system. Stockholm: Almqvist \& Wiksell International.

Zubrick, B., Reid, I., \& Rossiter, P. (2001). Strengthening the Nexus between Teaching and Research. Department of Education, Training and Youth Affairs: Canberra. 